Rev. Téc. Ing. Univ. Zulia. Vol. 43, No. 1, 2020, 49-55

\title{
Sorption characteristics of peeled beans and shells of fermented and dry Trinitario cocoa beans (Theobroma cacao L.)
}

\author{
Aleida J. Sandoval* (D), José A. Barreiro $\mathbb{D}^{2}$, Andrea De Sousa $\mathbb{D}$, Daniela Blanco and \\ César Giménez
}

Laboratorio de Procesamiento de Alimentos. Depto. de Tecnología de Procesos Biológicos y Bioquímicos, Universidad Simón Bolívar, Aptdo. 89000, Caracas 1080-A, Venezuela.

*Autor de contacto: asandova@usb.ve

https://doi.org/10.22209/rt.v43n1a07

Recepción: 03/12/2019 | Aceptación: 12/12/2019 | Publicación: 20/12/2019

\begin{abstract}
Water sorption data of the peeled bean and shell of Trinitario fermented and dry cocoa beans were determined at $25^{\circ} \mathrm{C}$ and adjusted to the isotherm models of Brunauer-Emmet-Teller-(BET) and Guggenheim-Anderson-de Boer-(GAB). The difference in the moisture sorption capacity of the shell and peeled beans was clearly established. The monolayer water contents estimated using the BET and GAB models for the peeled bean was 3.53 and $3.60 \mathrm{~g}$ water/100 g dry solids, respectively; while for the shell were 8.42 and $8.50 \mathrm{~g}$ water $/ 100 \mathrm{~g}$ dry solids. The energy constants $(C)$ obtained applying the BET model for the peeled bean and shell were 154.3 and 163.2, respectively. Those estimated from the GAB model $(C)$ were 21.63 and 83.56, respectively. A larger $C^{\prime}$ value for the shell indicates stronger water binding to the active sites in the monolayer as compared with the peeled beans that could indicate the presence of more active polar sites in the former. The value of the $K$ constant in the GAB model was 0.871 and 0.942 for the peeled bean and shell respectively that could suggest a larger water adsorption by proteinaceous material in the peeled bean.
\end{abstract}

Keywords: Sorption isotherms; BET and GAB; cocoa beans; cocoa bean shell; peeled cocoa bean.

\section{Características de sorción del haba pelada y la cascarilla de cacao Trinitario (Theobroma cacao L.) fermentado y seco}

\section{Resumen}

Se determinaron los datos de sorción de humedad de la cascarilla y habas peladas de cacao Trinitario, fermentado y seco a una temperatura de $25^{\circ} \mathrm{C}$ y se ajustaron a los modelos de Brunauer-Emmet-Teller-(BET) y Guggenheim-Anderson-de Boer(GAB). El contenido de agua de la monocapa para el haba pelada se estimó utilizando los modelos BET y GAB en 3,53 y 3,60 $\mathrm{g}$ de agua/100 g de sólidos secos, respectivamente; mientras que para la cascarilla fueron de 8,42 y 8,50 g de agua/100 g de sólidos secos. La constante de energía $(C)$ obtenida al aplicar el modelo BET para el haba pelada y la cascarilla fueron 154,3 y 163,2, respectivamente. Aquéllas calculadas con el modelo GAB ( $C$ ) fueron de 21,63 y 83,56. Un valor mayor de $C^{\prime}$ para la cascarilla indicó una mayor unión del agua a los sitios activos en la monocapa en comparación con el haba pelada, lo que podría evidenciar la presencia de sitios polares más activos en el primero. El valor de la constante $K$ en el modelo GAB fue 0,871 y 0,942 para el haba pelada y la cascarilla, respectivamente, pudiendo sugerir una mayor adsorción de agua por el material proteico en el haba pelada.

Palabras clave: datos de sorción; BET y GAB; habas de cacao; cascarillas; habas peladas. 


\section{Introduction}

Cocoa beans are a tropical product obtained from the pods of the cocoa tree (Theobroma cacao L.). It is an important commodity used in the manufacture of chocolate and chocolate products with applications in other industries. Once harvested, the pods are opened and the beans that are covered by mucilage rich in carbohydrates, allow to ferment in fermentation boxes at ambient temperature. The fermentation process involves multiple microorganisms and enzymatic transformations that impart to the beans the characteristic flavor and aroma. The fermented beans are sun-dried or artificially dried and packed in new permeable jute or similar sacks. The stability and preservation of cocoa beans depends on their moisture content, which is affected by temperature and air relative humidity, and ultimately by their water activity. Moisture sorption isotherms correlate the moisture content of a product with its water activity at constant temperature when it is in equilibrium with an ambient of known relative humidity. When the product with a determined moisture content is exposed to the ambient during storage or transportation, it can gain or lose moisture depending on the psychrometric conditions of air. Therefore, the knowledge of the moisture sorption isotherms is important to predict the stability of cocoa beans and carry out engineering calculations.

Water sorption isotherms of cocoa beans at elevated temperatures have been determined for the artificial drying: 33.3 to $52.4^{\circ} \mathrm{C}$ [1]; 20 to $70{ }^{\circ} \mathrm{C}$ [2]; 40 to $55^{\circ} \mathrm{C}$ [3], among others. Akmel et al. [4] presented water desorption isotherms for fermented cocoa beans at 30, 40 and $60{ }^{\circ} \mathrm{C}$. The data for 30 and $40{ }^{\circ} \mathrm{C}$ was coincident and there were no differences in sorption data with temperature in this range.

Sorption moisture isotherms for cocoa beans at ambient temperatures found in tropical zones (i.e., up to $40^{\circ} \mathrm{C}$ ) are scarce in the scientific literature. Gane [5] obtained moisture sorption data for cocoa beans for water activities below 0.70 using the static jar method at 15 and $37^{\circ} \mathrm{C}$. Sandoval and Barreiro [6], presented water sorption isotherms for non-fermented cocoa beans at temperatures of 25,30 and $35^{\circ} \mathrm{C}$. There were no significant differences $(p \leq 0.05)$ in water sorption in the temperature range studied and all data was adjusted to a single isotherm. The water sorption characteristics of cocoa powder obtained from fermented cocoa beans in at temperatures of 5, 15 and $30{ }^{\circ} \mathrm{C}$ was studied by Sandoval et al. [7]. As in the previous research, there were no significant differences ( $p$ $<0.05$ ) between the moisture sorption characteristics in the temperature range studied and the data was adjusted to a single isotherm in that range. In both papers, the monolayer water content was estimated using the BET model.

All works regarding the sorption isotherms for fermented and non-fermented cocoa beans at temperatures from 5 to $40{ }^{\circ} \mathrm{C}$ indicated that there were no significant differences in the water sorption characteristics in this temperature range, and the moisture sorption isotherms could be assimilated to a single isotherm [4, 6-7]. A different behavior was found for elevated temperatures involved in the artificial drying process of cocoa beans [2-3].

Sandoval et al. [8, 9] studied the physical properties and the composition and thermogravimetric characteristics of well fermented and dry Trinitario cocoa beans. The weight fraction estimated for the peeled bean was 0.845 and that of the shell 0.155 in relation to the whole bean weight. However, a significant difference was found between the moisture content of the shells $(17.30 \%$, w.b.) and that of the peeled bean (6.22\%, w.b.), evidencing different water sorption capacity. It was pointed out that the shell with $15.5 \%$ of the weight and average thickness of $0.310 \mathrm{~mm}$, was able to retain $39.7 \%$ of the total water present in the whole bean. This evidenced that the moisture distribution in cocoa beans was not uniform and it could have incidence in the water vapor diffusion and adsorption processes within the cocoa bean. These findings could have application in modeling and design work, particularly to study mass transfer and stability problems of cocoa beans and to better understand the phenomenon of moisture migration in dry containers and ship holds or while stored in warehouses that could result in condensation damage and eventual deterioration of the cocoa beans.

No information was found in the scientific literature revised regarding the sorption isotherms of cocoa beans components (shells and peeled beans). The objective of this research work was to determine the moisture sorption isotherm of shells and peeled fermented and dry Trinitario cocoa beans at $25{ }^{\circ} \mathrm{C}$ and determine the model that best fit and predict the experimental data.

\section{Materials and methods}

\section{Sample collection}

A composite sample of about $5 \mathrm{~kg}$ of fermented and dry cocoa beans (Theobroma cacao L.) Trinitario type, selected at random from beans packed in new and clean jute sacks was provided by Cacao de Origen, Hacienda La Trinidad, Caracas, Venezuela. The cocoa beans had been grown and harvested at Cúpira, Miranda state, Venezuela, in 2014. The cocoa beans had been graded as well fermented first grade (Fino de Primera) by the same, according to the Venezuelan standard for grading cocoa beans [10]. A sample of about $1000 \mathrm{~g}$ was selected at random for peeling to obtain the cocoa bean shells and the peeled cocoa beans used in this work.

Cocoa beans were carefully peeled by hand in the laboratory using a knife to separate the cocoa bean shell and obtain the peeled bean. The samples so prepared 
were kept at an average temperature of $25^{\circ} \mathrm{C}$ in a hermetic flask protected from ambient moisture in a dark place until they were used for analysis and further testing.

\section{Physical and chemical characterization}

The moisture content was determined using the atmospheric drying method at $100-102{ }^{\circ} \mathrm{C}$ for 16 hours until constant weight, following the procedure indicated in [11]. The water activity of the prepared samples was determined using a Decagon CX-1 equipment previously calibrated according to the operation manual [12].

The fraction of peeled cocoa bean and shell was determined following the procedure presented by Sandoval et al. [8]. Five hundred beans were selected at random and divided into five sub-samples. The weight of whole cocoa beans, shells and peeled beans was determined for each sub-sample using an analytical balance Ohaus Adventurer $( \pm 0.0001 \mathrm{~g}$ ); and the shell and the peeled bean fractions calculated. Also, the shell thickness was determined by selecting at random 100 pieces of shells and measuring their thickness in triplicate with a digital Mitutoyo micrometer $( \pm 0.001 \mathrm{~mm})$.

Chemical analyses for this product were done and presented in a previous research work [8]. For easy reference, the proximate composition is presented here $(\mathrm{g} / 100 \mathrm{~g} \pm$ standard deviation $)$ : Moisture $=6.51 \pm 0.05$; fat $=44.23 \pm 0.30$; protein $=12.65 \pm 0.22$; ash $=3.34 \pm$ 0.03 [8].

\section{Moisture sorption isotherms}

In order to determine the moisture sorption isotherms, the peeled cocoa beans and shells were separately ground in a motorized mill (Wiley $\mathrm{N}^{\circ} 4$ ), using a 2-mm sieve. A static gravimetric method was followed weighing of about $2 \mathrm{~g}$ of the ground samples (peeled bean or shells). The samples were placed in open shallow containers ( $3.8 \mathrm{~cm}$ in diameter) filled to a height of about $0.6 \mathrm{~cm}$. The containers with the samples were placed by triplicate inside desiccators, each one containing an oversaturated salt solution of known equilibrium relative humidity at the temperature studied. Eleven oversaturated salt solutions were used. These solutions covered a water activity range from 0.08 to 0.97 at $25^{\circ} \mathrm{C}$. The following salts and the corresponding water activities at $25^{\circ} \mathrm{C}$ in parenthesis were used [13]: $\mathrm{KOH}$ (0.082), LiCl (0.113), $\mathrm{KCH}_{3} \mathrm{CO}_{2}(0.225), \mathrm{MgCl}_{2}(0.328), \mathrm{K}_{2} \mathrm{CO}_{3}(0.432), \mathrm{Mg}\left(\mathrm{NO}_{3}\right)_{2}$ (0.529), $\mathrm{CoCl}_{2}$ (0.649), $\mathrm{NaCl}$ (0.753), $\left(\mathrm{NH}_{4}\right)_{2} \mathrm{SO}_{4}$ (0.810), $\mathrm{KNO}_{3}(0.936)$ and $\mathrm{K}_{2} \mathrm{SO}_{4}$ (0.973). Thymol was used as antifungal agent in the desiccators with ambient with relative humidity above $81 \%$ to avoid alterations by mold growth that could affect the results of the experiments [14]. The static gravimetric (SG. The desiccators with the samples were kept in an ambient at $25^{\circ} \mathrm{C}$.

In order to determine when equilibrium was reached, an identical setup was prepared in parallel for each salt. In this experiment, the samples were periodically weighed using an analytical balance (Ohaus Adventurer; \pm $0.0001 \mathrm{~g}$ ) until reaching constant weight at equilibrium. Also, after equilibrium was reached, the water activity of the samples was measured using a Decagon CX-1 equipment, in order to compare the water activity of the samples with those given by the oversaturated salt solutions.

The moisture content of the equilibrated samples determined by the oven method described before were correlated with the water activities of the corresponding salt solutions. The data obtained were adjusted to the sorption models of BET [15] and GAB [16-18] given in equations (1) and (2), respectively.

$$
V=\frac{V_{m} C a_{w}}{\left(1-a_{w}\right)\left[1+(C-1) a_{w}\right]}
$$

Where:

V: moisture content (g water $/ 100$ g dry solids)

$a_{w}:$ water activity (dimensionless)

$V_{m}$ : moisture content corresponding to the monomolecular layer (g water/100 g dry solids)

C: energy constant related to the free energy of sorption (dimensionle $_{\mathrm{ss}}$

In order to select the data for the adjustment to the BET equation (1), the recommendations given by [19] were followed. According to these recommendations, the application of the BET equation should be restricted to a water activity range where the term $V .\left(1-a_{w}\right)$ continuously increases when plotted as a function of $a_{w}$. The selection of a wrong range of water activity could result in negative values of the term $C$ which is physically unsound. This problem arises by the impossibility of separating the monolayer adsorption given by the BET equation from the multilayer adsorption and micropore filling which affect the $C$ value.

For the GAB model:

Where:

$$
V=\frac{V_{m}^{\prime} C^{\prime} K a_{w}}{\left(1-K a_{w}\right)\left(1-K a_{w}+C^{\prime} K a_{w}\right)}
$$

$V_{m}^{\prime}$ : moisture content corresponding to the monomolecular layer (g water/100 g dry matter)

$C^{\prime}$ : energy constant related to the free energy of sorption (dimensionless)

$K$ : constant related to the properties of the multilayer molecules relative to the bulk liquid

(dimensionless) 
The constants $K$ and $C^{\prime}$ should fulfill the following relations: $0<K \leq 1$, while $C^{\prime}>0$. For values of $C^{\prime} \geq 2$, the GAB equation turns into a Type II sigmoidal shape curve. However, for $0<C^{\prime}<2$, it results in a Type III isotherm [20, 21] the two-parameter BET (Brunauer-Emmett-Teller. $C^{\prime}$ is a constant related to the difference in enthalpy between monolayer $\left(\mathrm{H}_{1}\right)$ and multilayer $\left(\mathrm{H}_{\mathrm{m}}\right)$ sorption, and is expected to be positive due to the exothermic nature of the interaction of water with the active sites in the surface. The constant $K$ is related to the difference between the heat of condensation $\mathrm{H} \lambda$ of water and the heat of sorption of the multimolecular layer $\left(\mathrm{H}_{\mathrm{m}}\right)$. This difference is expected to be negative and smaller since the multilayer molecules are less firmly bound [22].

\section{Statistical analysis}

Comparison of central tendency of the equilibrium mositure contents of shell and peeled beans was done by means of one-factor analysis of variance (ANOVA). Non-linear regression was performed to fit sorption models of BET and GAB. In all cases, OriginPro 8.5.0 SR1 (Northampton, MA, U.S.A.) software was used. This software also evaluates the significance of such nonlinear regressions.

\section{Results and discussion}

\section{Physical Characterization}

The moisture content obtained for the cocoa bean samples was $6.51 \pm 0.05 \%$ (wet basis) with a range from 6.48 to $6.59 \%$ (wet basis). Its water activity at 25$27^{\circ} \mathrm{C}$ was 0.657 . The \pm sign indicates standard deviation.

The weight fraction determined for the shells in relation to the whole bean was 0.147 while the weight fraction for the peeled beans was 0.853 . These findings were similar to those presented by Sandoval et al. [8] for Trinitario fermented and dry cocoa beans who reported a weight fraction for the shell of $0.155 \pm 0.004$ with a $95 \%$ confidence interval from 0.146-0.165. The shell thickness determined was $0.21 \pm 0.03 \mathrm{~mm}$.

The moisture content of the peeled beans was $5.21 \pm 0.11 \mathrm{~g}$ water $/ 100 \mathrm{~g}$ dry solids and the moisture determined for the shells was $18.76 \pm 0.67 \mathrm{~g}$ water/100 g dry solids. Based on these results it was calculated that $35.6 \%$ of the water in the whole bean was contained in the shell and the rest in the peeled bean. These results are indicative of the higher water adsorption capacity of the cocoa bean shell as compared with that of the peeled bean. The difference in the water adsorption capacity of the shell and the peeled been and the possible causes were previously discussed by Sandoval et al. [8], considering the physicochemical changes that take place during cocoa bean fermentation presented by Lagunes Galvez et al. [23] and Afoakwa [24]. The microbiological and enzymatic activity taking place during fermentation results in the formation of compounds capable of adsorbing water such as reducing sugars, peptides, free aminoacids, organic acids and minerals. These compounds are mainly associated to the external area of the bean (shell) where most of the fermentation occurs.

\section{Moisture sorption isotherms}

In order to clarify the difference in the moisture sorption capacity of shells and peeled cocoa beans, the moisture sorption isotherms of these components of Trinitario fermented and dried cocoa beans were determined at $25{ }^{\circ} \mathrm{C}$. Since the initial moisture content of the peeled beans and shells was 5.21 and $18.76 \%$ (dry basis) respectively, the moisture data in the isotherms below the initial moisture content were obtained by desorption and those above by adsorption. The sorption data obtained for the shell and peeled bean are presented in Table 1.

Table 1. Sorption data of shell and peeled cocoa beans at $25{ }^{\circ} \mathrm{C}$ (average moisture content \pm standard deviation)

\begin{tabular}{|c|c|c|}
\hline & \multicolumn{3}{|c|}{ Moisture content (g/100 g of dry solids) } \\
$\boldsymbol{a}_{\boldsymbol{w}}$ & Peeled bean & Shell \\
\hline 0.082 & $3.39 \pm 0.07$ & $8.50 \pm 0.46$ \\
\hline 0.113 & $4.10 \pm 0.14$ & $9.14 \pm 0.05$ \\
\hline 0.225 & $4.34 \pm 0.27$ & $10.79 \pm 0.50$ \\
\hline 0.328 & $4.67 \pm 0.03$ & $12.32 \pm 0.11$ \\
\hline 0.432 & $4.75 \pm 0.05$ & $14.65 \pm 0.67$ \\
\hline 0.529 & $5.13 \pm 0.09$ & $15.28 \pm 0.93$ \\
\hline 0.649 & $5.50 \pm 0.30$ & $19.26 \pm 2.59$ \\
\hline 0.753 & $7.39 \pm 0.02$ & $27.16 \pm 1.99$ \\
\hline 0.810 & $9.13 \pm 0.13$ & $32.37 \pm 4.26$ \\
\hline 0.936 & $19.68 \pm 0.18$ & $72.70 \pm 9.20$ \\
\hline 0.973 & $24.55 \pm 0.07$ & $\mathrm{n} / \mathrm{d}^{*}$ \\
\hline \multicolumn{3}{|c|}{} \\
\end{tabular}

Table 1 clearly shows significant differences ( $p$ $<0.05$ ) between the average moisture sorption capacity of shell and peeled beans. For a given water activity, the moisture content of the shell was significantly higher $(p<0.05)$ than that of the peeled bean. This increased moisture adsorption capacity of shells can be explained by the water-binding compounds formed during bean fermentation by microbiological and enzymatic action. Most of the microbiological action during fermentation occurs in the surface of the beans where most of these compounds are localized [8,23-24].

The data in Table 1 was adjusted to the models of BET and GAB using the non-linear curve fit software OriginPro 8.5.0. The results are shown in Figures 1 and 2, respectively. The bars in each point indicate the standard error. 


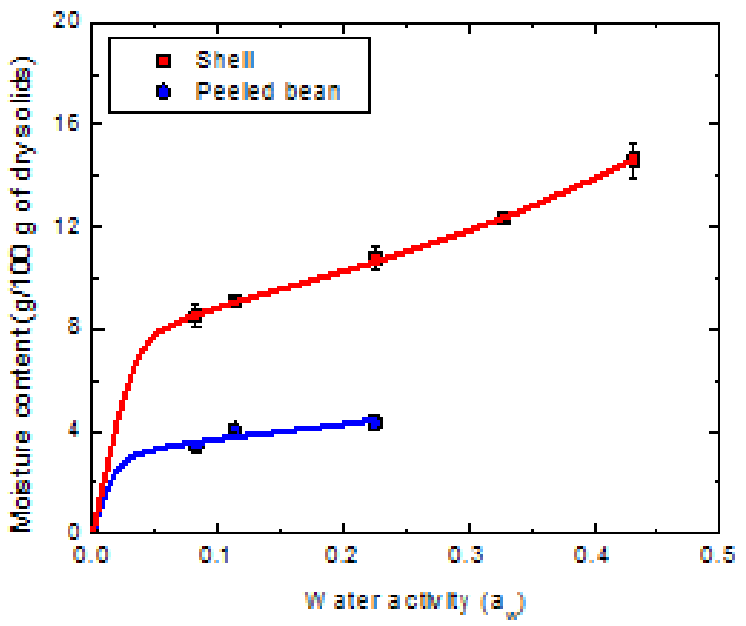

Figure 1. BET model moisture sorption isotherms for the shell and peeled beans at $25^{\circ} \mathrm{C}$

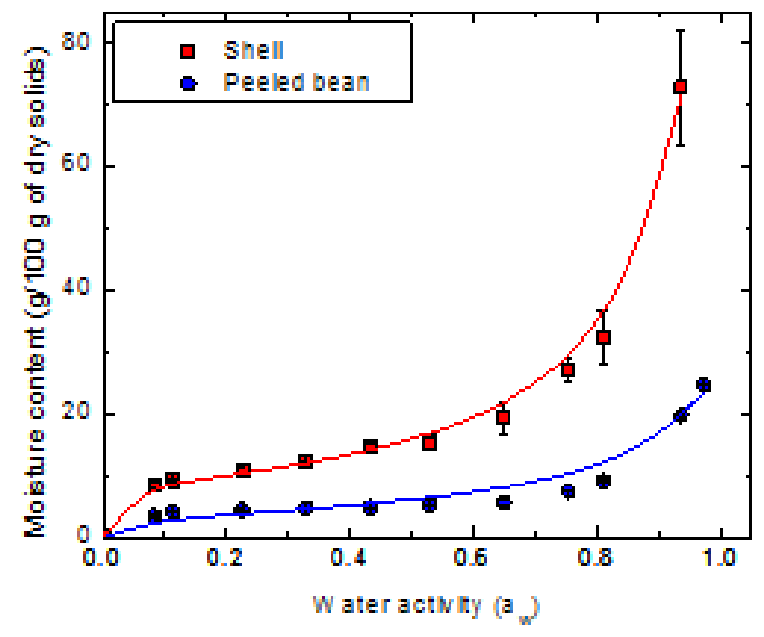

Figure 2. GAB moisture sorption isotherms for the shell and peeled bean at $25^{\circ} \mathrm{C}$

The data points taken in Figure 1 for the shell and the peeled bean used to adjust the BET model, were selected according to the guidelines given by Thommes et al. [19]. Hence, four points were taken for the peeled beans and six for the shell, including the origin.

The adjustment for the GAB equation included data points for water activity ranging from 0 to 0.973 for the peeled bean and from 0 to 0.936 for the shell. The constants obtained from the non-linear adjustment: $V_{m}$ and $C$ for the BET model and $V_{m}^{\prime}, C^{\prime}$ and $K$ for the GAB model are presented in Table 2.
Table 2. Constant parameters obtained for the BET and GAB sorption models

\begin{tabular}{cccc}
\hline \multirow{2}{*}{ Model } & Parameter & \multicolumn{2}{c}{ Cocoa component } \\
& Peeled bean & Shell \\
\hline \multirow{2}{*}{ BET } & $V m$ & 3.53 & 8.42 \\
& & & \\
& $C$ & 154.3 & 163.2 \\
& R2 & 0.987 & 0.999 \\
GAB & $V_{m}^{\prime}$ & 3.60 & 8.50 \\
& $C^{\prime}$ & 21.64 & 83.56 \\
& $K$ & 0.871 & 0.942 \\
& $\mathrm{R} 2$ & 0.949 & 0.993 \\
\hline
\end{tabular}

Table 2 shows that in all cases elevated correlation coefficients $\left(\mathrm{R}^{2}\right)$ were obtained for the statistical adjustment of the data to the BET and GAB models. The analysis of variance carried out for both models (not shown) presented highly significant nonlinear regressions $(\mathrm{p}<0.001)$.

The monolayer water content $\left(V_{m} V_{m}^{\prime}\right.$ and $)$ of the shell was higher than that obtained for the peeled bean in both models, evidencing the presence of more active sites capable of binding water in the shell, as discussed before. When using the BET model, $C$ values of 154.3 and 163.2 were obtained for the peeled bean and shell, respectively. The values obtained were in the same order magnitude to those reported by Sandoval and Barreiro [6] and Sandoval et al. [7] for whole cocoa beans, using the BET model of 2.94 and $3.56 \mathrm{~g} / 100 \mathrm{~g}$ dry solids, respectively.

The estimated GAB constants were: monolayer water content $\left(V_{m}^{\prime}\right)$ of 3.60 and $8.50 \mathrm{~g} / 100 \mathrm{~g}$ of dry solids; $C^{\prime}$ values of 21.64 and 83.56 ; and $K$ values of 0.871 and 0.942 , for the peeled bean and shell, respectively. The results obtained comply with the inequalities summarized by Timmermann [20] the two-parameter BET (BrunauerEmmett-Teller and Blahovec and Yanniotis [21], in the sense that $V m<V_{m}^{\prime}$ and $C>C^{\prime}$ with $K \leq 1$ indicating the physical soundness of the results.

The larger $C^{\prime}$ value obtained for the shell indicates stronger water binding to the active sites in the monolayer as compared with the peeled beans, evidencing the presence of more active polar sites in the former. $C^{\prime}$ is related to the difference between the free enthalpy of water molecules adsorbed in the multilayer 
and that of the molecules bound to the monolayer. The $K$ value obtained for the shell was close to one $(0.942)$, indicating small difference between the molecules in the multilayer and non-bound molecules in the bulk of liquid. As $K$ approaches to one, the water molecules beyond the monolayer are not structured in a multilayer and have similar characteristics as those in the bulk liquid and the GAB equation is reduced to the BET model [22]. A smaller $K$ value was obtained for peeled beans $(0.871)$ indicating structuration of a sorption multilayer. According to Chirife et al.[25], the value of $K$ for proteins falls in a range of 0.82 - 0.88 while for starchy products falls in the range 0.70 0.77 . This could indicate predominant water adsorption by proteinaceous material in the peeled bean.

\section{Conclusions}

The water sorption data of shell and peeled cocoa beans were determined and adjusted using nonlinear curve fitting to the isotherm models of BET and GAB. The analysis of variance for both models showed highly significant non-linear regressions ( $p<0.001)$, for the peeled bean and the shell and elevated correlation coefficients

The difference in the moisture sorption capacity of the shell and peeled beans was clearly established. The monolayer water content calculated using the BET $(\mathrm{Vm})$ and GAB $\left(V_{m}^{\prime}\right)$ models for the peeled bean was 3.53 and $3.60 \mathrm{~g}$ water $/ 100 \mathrm{~g}$ dry solids, respectively; while for the shell were 8.42 and $8.50 \mathrm{~g}$ water $/ 100 \mathrm{~g}$ dry solids. The $C$ values obtained using the BET model for the peeled bean and shell were 154.3 and 163.2 , respectively and $C^{\prime}$ values of 21.63 and 83.56 were calculated when the GAB model was applied. A larger $C^{\prime}$ value for the shell indicates stronger water binding to the active sites in the monolayer as compared with the peeled beans that could evidence the presence of more active polar sites in the former. The value of the $K$ constant in the GAB model was 0.871 and 0.942 for the peeled bean and shell respectively that could suggest a largest water adsorption by proteinaceous material in the peeled bean.

\section{References}

[1] Mercier, P., Tusa, A. y Guaíquirian, H.: Adsorción del agua en semilla de café y cacao. Acta Científica Venez, Vol. 33, No. 1 (1982), 398.

[2] Talib, M., Daud, W. and Ibrahim, M.: Moisture desorption isotherms of cocoa beans. Trans. ASAE, Vol. 38, No. 4 (1995) 1153-1155.

[3] Kanmogne, A., Jannot, Y., Lips, B., Nganhou, J.: Sorption isotherms and drying characteristic curve offermented cocoa. Int. J. Sci. Technol., Vol. 2, No. 4 (2012), 19-31.

[4] Akmel, D.C.. Kakou, K. E., Kone, K.Y., Assidjo,
N.E. and Kouame, P.: Desorption isotherms and isosteric heats of fermented cocoa beans (Theobroma cocoa). J. Food Res., Vol. 4, No 3 (2015) 138-147.

[5] Gane, R.: The water relations of some dried fruits, vegetables and plant products. J. Sci. Food Agric., Vol. 1, (1950) 42, 1950.

[6] Sandoval, A.J. and Barreiro, J.A.: Water sorption isotherms of non-fermented cocoa beans (Theobroma cacao). J. Food Eng., Vol. 51, No. 2 (2002) 119-123.

[7] Sandoval, A.J., Barreiro, J.A., Tovar, X. and Angueira, M.: Sorption characteristics of fermented cocoa powder (Theobroma cacao). Rev. Tec. la Fac. Ing. Univ. del Zulia, Vol. 25, No. 1 (2002) 49-55, 2002.

[8] Sandoval, A.J., Barreiro, J.A., De Sousa A., Valera D., López, J.V. and Müller, A.J.: Composition and thermogravimetric characterization of components of Venezuelan fermented and dry Trinitario cocoa beans (Theobroma cacao L.): Whole beans, peeled beans and shells. Rev. Técnica la Fac. Ing. Univ. del Zulia, Vol. 42, No. 1 (2019) 39-46.

[9] Sandoval, A.J., Barreiro, J.A., De Sousa A., Valera D., \& Müller, A. J.: Determination of the physical properties of fermented and dried beans of Venezuelan Trinitario cocoa (Theobroma cacao L.). Rev. Técnica la Fac. Ing. Univ. del Zulia, Vol. 42, No. 2 (2019) 50-56.

[10] Norma Venezolana Covenin 50:1995. Granos de cacao (2da revisión). Ministerio de Fomento. Caracas, Venezuela, 1995.

[11] AOAC. Official Methods of Analysis of the Association of Official Analytical Chemists. 16th ed. Arlington, VA, 1996.

[13] Greenspan, L.: Humidity fixed points of binary saturated aqueous solutions. J. Res. Natl. Bur. Stand. Sect. A Phys. Chem., Vol. 81A, No. 1 (1977) 89-96.

[14] Sandoval, A.J., Guilarte, D., Barreiro, J. A., Lucci E. and Müller, A. J.: Determination of moisture sorption characteristics of oat flour by static and dynamic techniques with and without thymol as an antimicrobial agent. Food Biophys., Vol. 6, No. 3 (2011) 424-432.

[15] Brunauer, S., Emmett, P. and Teller, E.: Adsorption 
of gases in multimolecular layers. J. Am. Chem. Soc., Vol. 60, No. 2 (1938) 309-319.

[16] Guggenheim, E. Applications of Statistical Mechanics. Oxford: Clarendon Press. UK., 1966.

[17] Anderson, R.: Modifications of the BET equation. J. Am. Chem. Soc., Vol. 68, No. 4 (1946) 689-691, 1946.

[18] De Boer, v.H.J.: The Dynamic Character of Adsorption. 2nd. Oxford: Clarendon Press. UK, 1953.

[19] Thommes, M., Kaneko, K., Neimark, A., Olivier, J., Rodriguez-Reinoso, F., Rouquerol, J. and Sing, K.: Physisorption of gases, with special reference to the evaluation of surface area and pore size distribution (IUPAC Technical Report). Pure Appl. Chem., Vol. 87, No. 9-10 (2015) 1051-1069.

[20] Timmermann, E.O.: Multilayer sorption parameters: BET or GAB values?. Colloids Surfaces A Physicochem. Eng. Asp., Vol. 220, No. 1-3 (2003) 235-260.
[21] Blahovec, J. and Yanniotis, S.: Generalized equation for sorption phenomena. Food and Bioprocess Technology. Food Bioprocess Technol., Vol. 1, No. 1 (2008) 82-90.

[22] Quirijns, E., van Boxtel, A., van Loon, W. and van Strate, G.: Sorption isotherms, GAB parameters and isosteric heat of sorption. J. Sci. Food Agric., Vol. 85, No. 11 (2005) 1805-1814.

[23] Lagunes Gálvez, S., Loiseau, G., Paredes, J.L., Barel, M. and Guiraud, J.P.: Study on the microflora and biochemistry of cocoa fermentation in the Dominican Republic. Int. J. Food Microbiol., Vol. 114, No. 1 (2007) 124-130.

[24] Afoakwa, E.O., Kongor, J.E., Takrama, J. and Budu, A.S.: Changes in nib acidification and biochemical composition during fermentation of pulp preconditioned cocoa (Theobroma cacao) beans. Int. Food Res. J., Vol. 20, No. 4 (2013) 1843-1853.

[25] Chirife, J., Timmermann, E.O., Iglesias, H.A., Boquet, R.: Some features of the parameter $\mathrm{k}$ of the GAB equation as applied to sorption isotherms of selected food materials. J. Food Eng., Vol. 15, No. 1 (1992) 75-82. 


\section{REVISTA TECNICA}

DE LA FACULTAD DE INGENIERIA

UNIVERSIDAD DEL ZULIA

Vol. 43. N`1, Enero - Abril 2020, pp. 03 - 56

Esta revista fue editada en formato digital y publicada en Diciembre de 2019, por el Fondo Editorial Serbiluz, Universidad del Zulia. Maracaibo-Venezuela

www.luz.edu.ve

www.serbi.luz.edu.ve

www.produccioncientifica.luz.edu.ve 